\title{
Clinical application of bergamot (Citrus bergamia) for reducing high cholesterol and cardiovascular disease markers
}

\author{
Mirielle C Nauman and Jeremy J Johnson* \\ Department of Pharmacy Practice, College of Pharmacy, University of Illinois at Chicago, USA
}

\begin{abstract}
The bergamot is a citrus fruit native to southern Italy with traditional uses that include improving immune response and cardiovascular function. There are a variety of phytochemicals that have been found in the bergamot including brutieridin and melitidin as well as other flavonoids, flavones O-glucosides and C-glucosides. Multiple clinical trials have provided evidence that different forms of orally administered bergamot can reduce total cholesterol and low-density lipoprotein cholesterol. In vitro mechanistic studies have provided evidence that polyphenols from the bergamot can alter the function of AMPK and pancreatic cholesterol ester hydrolase (pCEH). The use of bergamot in multiple clinical trials has consistently shown that it is well tolerated in studies ranging from 30 days to 12 weeks. This mini-review reports on the clinical studies performed with different forms of bergamot along with their effectiveness in reducing total cholesterol and LDL cholesterol in patients with hypercholesterolemia.
\end{abstract}

\section{Background}

Citrus fruits are rich in flavonoids and have long been associated with improving human health outcomes in areas that include improved immune response, coronary artery disease, heart failure, and high cholesterol. One citrus fruit in particular that has gained attention for improving health outcomes is the bergamot (Citrus bergamia) [1]. This fruit is primarily found in Southern Italy in the area known as Calabria with attributes that include antioxidant, anti-inflammatory, and cholesterol reducing functions [2,3]. In Italian traditional medicine the bergamot has been used to treat or cure a variety of symptoms that include fever, sore throat, mouth and skin infections, and infections of the respiratory system and the urinary tract [1]. Recent studies have validated the anti-microbial properties of bergamot in in vitro settings [4-6].

Dyslipidemia is an important risk factor for the development of atherosclerosis and eventual coronary artery disease. Dyslipidemia is evidenced by increased concentrations (i.e. hyperlipidemia) of low-density lipoprotein cholesterol (LDL-C), total blood cholesterol, and triglycerides. Hyperlipidemia is often accompanied by insulin resistance including impaired glucose tolerance, or "pre-diabetes", and low levels of high-density lipoprotein cholesterol (HDL-C) [7]. The three most common pharmacological approaches to lowering hypercholesterolemia include bile acid sequestrants, statins, and inhibitors of cholesterol absorption (i.e. ezetimibe). Of these three, the statin family represents the most favored approach as evidenced by current protocols favoring statin use, annual sales of statins, and clinical studies suggesting significant reductions in cardiovascular events, morbidity, and mortality with statins [8]. The primary mechanism of statins includes the inhibition of the enzyme catalyzing the ratelimiting step in mevalonate biosynthesis. This key intermediate in cholesterol metabolism is essential for de novo cholesterol synthesis. Along with the inhibition of cholesterol synthesis, there are known dose related side effects shown in estimates as high as $22 \%$ of patients utilizing statins, including liver disease or severe myopathy $[9,10]$. Given the documented benefits of lowering LDL-C, triglycerides, and total cholesterol, additional dietary and phytochemical approaches should be investigated as alternative methods to reducing indices of hyperlipidemia. One such example includes the bergamot fruit that has been investigated in pre-clinical and clinical studies for improving dysplipidemia.

The tree Citrus bergamia belonging to the Rutaceae family is found in the Calabria region specifically, due to its unique climate that is suitable for its growth. Essential oils of the bergamot peel are well characterized and used extensively in products ranging from the food industry, pharmaceutical industry, and the cosmetic industry $[1,11]$. Previous studies have suggested that the essential oil contains up to $93-96 \%$ volatile phytochemicals that include monoterpenes (25$53 \%)$, linalool (2-20\%) and linalyl acetate (15-40\%). The non-volatile compounds include waxes, pigments, coumarins, and psoralens. The bergamot fruit also contains flavonoids that include neoeriocitrin, naringin and neohesperidin among many others that have been of interest for their cardiovascular benefits. In this review we will evaluate the clinical evidence for bergamot as a strategy for improving dyslipidemia.

*Correspondence to: Jeremy J Johnson, PharmD, PhD, Room 164, Department of Pharmacy Practice, College of Pharmacy MC886, University of Illinois, Chicago Illinois, 60612, USA, Tel: 3129964368; E-mail: jjjohn@uic.edu

Key words: bergamot, brutieridin, melitidin, cholesterol, antioxidant, Citrus bergamia

Received: February 03, 2019; Accepted: February 26, 2019; Published: February 28,2019 


\section{Phytochemical constituents of bergamot}

Though most citrus fruits are known to contain flavonoids, the bergamot is unique in that it contains an especially high content of flavonoids [12-15]. Neoeriocitrin, naringin and neohesperidin have all been isolated and identified in bergamot. C-glucoside flavonoids identified in bergamot include apigenin 6,8-di-C-glucoside, diometin 6,8-di-C-glucoside, lucenin-2, vicenin-2, stellarin-2, lucenin-2-40methyl ether, scoparin, and orientin 40-methyl ether; Flavone Oglycosides identified in bergamot include brutieridin, melitidin, rhoifolin 40-O-glucoside, chrysoeriol 7-O-neohesperidoside-40-Oglucoside, diosmin, rhoifolin, chrysoeriol 7-O-neohesperidoside, narirutin, and neodiosmin. Considering the high content of volatile compounds, it is unsurprising that the bergamot peel and many other citrus peels are widely used in the perfume and cosmetic industries. A study by Mondello et al. found that bergamot essential oil contains more than 100 volatile compounds while linalyl acetate and linalool were predominant in addition to limonene [16].

\section{Mechanism of action of phytochemicals from the ber- gamot}

\section{Inhibiting oxidation of LDL particles}

Oxidation of low-density lipoprotein particles is a harmful form of cholesterol that results from free radical damage. This form of oxidative damage, along with increased inflammatory events, has been associated with atherosclerosis that ultimately alters cardiovascular blood flow. Several constituents including naringin, neoeriocitrin, and rutin from the bergamot have been reported to lower the oxidation of LDL particles. Studies using naringin, neoeriocitrin and rutin reported them to have antioxidant activity in in vitro antioxidant models by beta-carotene-linoleic acid, 1,1-diphenyl-2-picryl hydrazyl (DPPH), superoxide, and hamster low-density lipoprotein (LDL) [17].

In another study, male New Zealand rabbits were fed a high cholesterol diet and divided into three groups as follows: 1) placebo (i.e. control group) 2) naringin and 3) lovastatin [18]. The results revealed that naringin significantly reduced fatty streak formation and macrophage infiltration in endothelial cells. In addition, naringin was found to be hepatoprotective while lovastatin was not found to be hepatoprotective. Naringin-inhibited-cholesterol also induced elevation of intercellular adhesion molecule-1 (ICAM-1) in endothelial cells. ICAM-1 levels have been reported to be elevated in response to normal immune function disruption in endothelial cells leading to atherosclerosis [19].

Reactive oxygen species (ROS) including superoxide $\left(\mathrm{O}_{2}^{-}\right)$, hydrogen peroxide $\left(\mathrm{H}_{2} \mathrm{O}_{2}\right)$, and hydroxyl radicals $\left(\mathrm{OH}^{-}\right)$can directly damage cells in the cardiovascular system and induce proinflammatory events. In addition, ROS can induce the formation of peroxynitrite $\left(\mathrm{ONOO}^{-}\right)$and is associated with neointima formation. This formation of scar tissue can also result from a balloon angioplasty procedure. An in vivo study evaluated the impact of bergamot on injured blood vessels following angioplasty in rats [20]. Pre-treatment of rats with the nonvolatile fraction of bergamot reduced free radical formation and Lectinlike oxyLDL receptor-1 (LOX-1). These results show that 14 days of consecutive administration of bergamot oil antagonized the effects of smooth muscle cell proliferation and neointima formation in the rat carotid artery following angioplasty.

Oxidized LDL leads to vasoconstriction mediated by the inflammatory thromboxane A2 [21]. Studies have suggested that glomerular injuries and hemodynamic abnormalities of the kidney may by directly caused by interaction of oxidized LDL with mesangial cells Wheeler et al. (1994). The renal protective properties of bergamot juice were tested in rats receiving a hyperlipidemic diet [22]. Bergamot juice $(1 \mathrm{~mL})$ was found to significantly decrease malondialdehyde (MDA) levels compared to hyperlipidemic controls $(4.10 \pm 0.10 \mathrm{nmol} /$ $\mathrm{mg}$ protein and $4.78 \pm 0.15 \mathrm{nmol} / \mathrm{mg}$ protein, respectively). Biochemical data also reported that histological preparations of the kidney suggests that bergamot juice prevented the development of renal damage from hypercholesterolemia.

\section{Hypolipidemic properties of bergamot polyphenols}

HMG-CoA reductase is the rate controlling enzyme in the mevalonate pathway that is responsible for cholesterol synthesis. The class of compounds known as statins are potent inhibitors of HMGCoA by competitively binding the active site where HMG binds. This makes HMG-CoA a valuable target for reducing cholesterol levels. A study by Di Donna et al. in 2009 proposed two molecules from bergamot, neohesperidin and naringin, as sharing structural similarity to statins [23]. A more recent study by Leopoldini reported through computational modelling that bergamot's statin-like molecules bind to HMG-CoA at Arg590, Ser684, Asp690, Lys692, and Lys735 residues, as well as at the nonpolar amino acids [24]. To date, there has not been any definitive in vitro validation that flavonoids from bergamot share a similar mechanism for inhibition of HMG-CoA reductase. Though no clinical trials have reported on the coenzyme Q10 levels following bergamot administration, it may be another possible benefit over statins, as statins are well known to decrease plasma levels of coenzyme Q10 [25].

A second mechanism that has been proposed with bergamot polyphenols is the activation of adenosine monophosphate-activated protein kinase (AMPK). Activation of AMPK by small molecules improves glucose homeostasis, lipid profiles, blood pressure and insulin resistance and is one of the proposed mechanisms of metformin. Naringin was found to promote phosphorylation of AMPK in the liver at threonine-172 in C57BL/6J mice receiving a high fat diet [26]. These results were further confirmed in HepG2 cells that were exposed to naringin. A study by Sui $e$ al. revealed that naringin activates AMPK altering the expression of proprotein convertase subtilisin/kexin type 9 (PCSK9), sterol regulatory element-binding proteins (SREBPs), and low-density lipoprotein receptor (LDLR) [27]. The results of this study identified naringin as an AMPK activator in mice, leading to a down-regulated expression of SREBPs and PCSK9, and an increased expression of LDLR to reduce the body weight of obese C57BL/6J mice. A statistically significant decrease in triglycerides, LDL and total cholesterol was observed. Increasing the expression of LDL receptor is beneficial for promoting the endocytosis of cholesterol rich LDL.

In vivo studies have reported that oral administration of bergamot juice can reduce blood cholesterol and improve the atherogenic index in mice. Hand pressed bergamot juice was administered to Wistar rats weighing 180 to 200 grams while being administered a high cholesterol diet [28]. The animal feed included cholesterol, $2 \%$; sodium cholate, $2 \%$; vitamin mixture, $2 \%$; oligoelements, $0.2 \%$; salt mixture, $5.8 \%$; coconut oil, $20 \%$; cellulose, $4 \%$; sucrose, $44 \%$; casein, $5 \%$; drakettprotein, $15 \%$. Animals were divided into three groups as follows: 1) normolipidemic control rats on a standard diet 2) hypercholesterolemic diet for 30 days and 3) hypercholesterolemic diet for 30 days receiving $1 \mathrm{~mL}$ of bergamot juice daily for 30 days. The main flavonoids identified in the present study were 1) neoeriocitrin (370 ppm), 2) naringin (520 ppm), 
and 3) neohesperidin (310 ppm). Bergamot juice was found to reduce cholesterol (29.27\%), triglycerides (46.12\%), and LDL (51.72\%) and an increase in HDL (27.61\%) levels versus hypercholesterolemic controls. The atherogenic index was $1.09 \pm 0.10$ in the C. bergamia-treated group as compared with $3.09 \pm 0.20$ in the hypercholesterolemic group.

Pancreatic cholesterol ester hydrolase (pCEH) represents an additional target in disrupting cholesterol synthesis. This enzyme catalyzes the hydrolysis of sterol esters into sterols and fatty acids. Disruption of this reaction can significantly improve the serum lipid profile in hyperlipidemic patients. An in vivo study identifies the bergamot polyphenol fraction as capable of disrupting pCEH [29]. Male Sprague-Dawley rats (200-225 g) received a normal diet or a high cholesterol diet. Rats receiving bergamot polyphenol fraction at $10 \mathrm{mg} /$ $\mathrm{kg}$ by oral gavage were found to inhibit pCEH activity.

\section{Clinical trials with bergamot for hypercholesterolemia}

\section{Mollace (2018)}

A randomized double-blind placebo-controlled study evaluated a bergamot polyphenol fraction for lowering hyperlipidemia [30]. Patients were randomized into three groups as follows: 1) placebo $(n=20) 2)$ bergamot polyphenol fraction $(\mathrm{n}=20)$ and 3$)$ bergamot polyphenol fraction phytosomal formulation $(n=20)$. Patients were enrolled in the study with mixed hyperlipidemia defined as LDL cholesterol $>120 \mathrm{mg} /$ $\mathrm{dl}$ and triglycerides $>175 \mathrm{mg} / \mathrm{dl}$, and serum glucose $>110 \mathrm{mg} / \mathrm{dl}$. Human subjects in the bergamot polyphenol fraction (BPF) group received 650 mg taken twice daily and subjects in the bergamot polyphenol fraction phytosomal formulation group (BPF Phyto) received $500 \mathrm{mg}$ taken twice daily; both were taken for 30 days. The bergamot polyphenol fraction decreased total cholesterol from 262 to 196, LDL cholesterol from 175 to 116 , and triglycerides from 252 to 170 . Similar results were observed with BPF Phyto: it decreased total cholesterol from 261 to 198, LDL cholesterol from 174 to 113 , and triglycerides from 252 to 173 . Both formulations were able to show an increase in HDL cholesterol with BPF increasing HDL from 44 to 48 and BPF Phyto from 44 to 50. Decreases in serum glucose were observed with BPF from 120 to 98 and BPF Phyto from 124 to 96 . No changes were observed in the placebo group. The results suggest that both formulations were able to significantly modify cholesterol levels after 30 days. A second outcome that was measured included the pharmacokinetics of key flavonoids found in bergamot including naringin, naringenin, and naringenin glucuronide. No significant differences existed between the two different formulations of bergamot in this clinical trial.

\section{Toth (2016)}

An open label clinical trial evaluated bergamot derived extract in 80 human subjects ( 42 men and 38 women, mean age $55 \pm 13$ ) with moderate hypercholesterolemia (i.e. $160-190 \mathrm{mg} / \mathrm{dl}$ ) [31]. The subjects received $150 \mathrm{mg}$ of bergamot flavonoids (standardized to contain $16 \%$ neoeriocitrin, $47 \%$ neohesperidin, and $37 \%$ naringin) daily for 6 months. Bergamot was observed to decrease total cholesterol from 255 to 224 , LDL cholesterol from 159 to 132, and triglycerides from 159 to 133. An increase in HDL was observed with bergamot from 50 to 54 . LDL was divided into 7 subclasses that included LDL-1 and LDL-2, representing large LDL, and LDL-3-7 representing atherogenic small, dense LDL. A significant increase in LDL-1 (from $41.2 \% \pm 0.2 \%$ to $49.6 \% \pm 0.2 \%, \mathrm{p}<0.0001$ ) was observed. A decrease in the small dense LDL-3, -4 , and -5 particles (from $14.5 \% \pm 0.1 \%$ to $9.0 \% \pm 0.1 \% \mathrm{p}<0.0001$; $3.2 \% \pm 0.1 \%$ to $1.5 \% \pm 0.1 \% \quad \mathrm{p}=0.0053 ; 0.3 \% \pm 0.0 \%$ to $0.1 \% \pm 0.0 \%$ $\mathrm{p}=0.0133$, respectively). Bergamot decreased cIMT from $1.2 \mathrm{~mm} \pm 0.4$ to $0.9 \mathrm{~mm} \pm 0.1(\mathrm{p}<0.0001)$.

\section{Babish (2016)}

An observational, one-arm study was conducted with 11 human participants ( 3 male and 8 female; age 38-65 years) and evaluated a combination of 9 plant extracts that included bergamot fruit extract [32]. The extract (i.e. F105) was formulated with apple fruit extract, bergamot fruit extract, blueberry fruit concentrate, capsicum fruit, grape seed extract, grape skin extract, green tea leaf extract, mangosteen pericarp extract, olive leaf extract, and turmeric root \& rhizome extract in a number of ratios beginning with $8.5 \%, 70.4 \%, 1.4 \%, 1.4 \%, 1.4 \%$, $1.4 \%, 4.2 \%, 1.4 \%, 1.4 \%$, and $8.5 \%$ representing $\mathrm{F} 105$, respectively. Patients were directed to take 2 capsules daily (total $500 \mathrm{mg}$ of bergamot fruit extract and $220 \mathrm{mg}$ phytochemical complex blend) for 12 weeks. A reduction of total cholesterol (7.3\%), LDL cholesterol (10\%), and apolipoprotein B (2.8\%) was observed. Changes in levels of lipoprotein(a), triglycerides, and HDL were observed, however, they were not statistically significant. Additionally, one patient who was non-responsive to statin therapy $(20 \mathrm{mg})$ was enrolled and was directed to take $720 \mathrm{mg}$ of F105 for the duration of the study during the evening meal. After 12 weeks, a reduction compared to baseline was observed with LDL $(-8 \%)$, total cholesterol $(-4 \%)$, triglycerides $(-34 \%)$, oxidized LDL $(-6 \%)$ and an increase in HDL (54\%) occurred. Clinical observations of this study suggest the F105 extract was safe and efficacious in lowering of lipid biomarkers.

\section{Gliozzi (2013)}

A prospective, open-label, parallel group, placebo-controlled study with 77 human subjects with elevated LDL and triglycerides were administered 1) placebo $(\mathrm{n}=15)$ 2) rosuvastatin $10 \mathrm{mg}(\mathrm{n}=16)$ 3) rosuvastatin $20 \mathrm{mg}(\mathrm{n}=16)$ 4) bergamot polyphenol fraction (BPF) $(n=15)$ or 5$)$ bergamot polyphenol fraction with rosuvastatin $(n=15)$ [33]. The total duration of the study was 30 days. Capsules containing $500 \mathrm{mg}$ of bergamot polyphenol fraction with $50 \mathrm{mg}$ of ascorbic acid were encapsulated for the study. The principle flavonoids in the bergamot polyphenol fraction were neoeriocitrin, naringin, and neohesperidin. Both doses of rosuvastatin and BPF reduced total cholesterol, LDL, and urinary mevalonate. The results of this study suggest a combination of rosuvastatin and BPF were safe when taken together for 30 days. Further research beyond 30 days would be needed to determine if rosuvastatin and BPF can safely continue to be taken in combination.

\section{Mollace (2011)}

A randomized, double-blind, placebo-controlled clinical trial evaluated bergamot (500 mg or 1,000 mg per day) for three months to reduce total cholesterol, reduce LDL, and increase HDL [34]. A total of 237 human subjects were enrolled in the study. Total cholesterol was reduced by $20 \%$ (500 mg of bergamot) and 30.9\% (1,000 mg of bergamot). LDL was reduced by $23 \%$ (500 mg bergamot) and by $38.6 \%$ (1,000 $\mathrm{mg}$ of bergamot). HDL was increased by $25.9 \%$ (500 $\mathrm{mg}$ of bergamot) and by $39 \%$ (1,000 mg of bergamot). In 6 patients treated daily with $500 \mathrm{mg}$ and in 11 patients taking $1000 \mathrm{mg}$ of BPF, a moderate gastric pyrosis was observed. However, none of the patients taking BPF interrupted the treatment. Interestingly, this study enrolled 32 human subjects who experienced statin toxicity. Prior to their enrollment to the bergamot study, human subjects stopped taking statins for 2 months. They were then administered $1500 \mathrm{mg}$ of BPF daily. After 30 days, those patients receiving BPF had changes in total cholesterol (-25\%) and LDL $(-27.6 \%)$ without reappearance of statin toxicity. Taken together, the results of this study suggest that BPF can reduce total cholesterol, LDL, and triglycerides. 


\section{Conclusion}

The results of five different clinical trials (Table 1) using bergamot in various forms suggest the polyphenol fraction can lower LDL-C and total cholesterol. Several studies suggested that bergamot polyphenols can reduce triglycerides and increase HDL-C, however, the results were not consistent across all studies. One possible explanation for this variability (i.e. TG and HDL-C) is that bergamot preparation, extraction, and standardization varied in several studies. Consistently in all of the clinical trials bergamot appeared to be well tolerated with studies ranging from 30 days to 6 months. There are several weaknesses in the design of several of the clinical trials that used an open label design (Table 1). However, it should be noted that each patient can serve as their own control since cholesterol was quantified prior to bergamot and at the completion of the study. Three of the studies suggested an increase in HDL by up to $4 \mathrm{mg} / \mathrm{dl}$ (Table 1). This is significant because HDL is often difficult to increase apart from lifestyle changes. Regarding the mechanism of action there are several possible mechanisms that may be responsible for improving cholesterol lab values including activation of AMPK and inhibition of pancreatic cholesterol ester hydrolase (pCEH). As of now the suggestions that bergamot inhibits HMG-CoA reductase appear

Table 1. Summary of clinical trials using bergamot for hypercholesterolemia

\begin{tabular}{|c|c|c|c|c|}
\hline $\begin{array}{l}\text { Authors } \\
\text { and year }\end{array}$ & Study design & Study agent(s) & Human subjects & Results \\
\hline $\begin{array}{l}\text { Mollace } \\
\text { (2018) }\end{array}$ & $\begin{array}{l}\text { Randomized, } \\
\text { double blind, } \\
\text { placebo- } \\
\text { controlled } \\
\text { Site: Catanzaro, } \\
\text { Italy }\end{array}$ & $\begin{array}{l}\text { 1. } 650 \mathrm{mg} \text { tablet twice daily of Bergamot Polyphenol Fraction } \\
\text { (BPF; } 38 \% \text { polyphenols) } \\
\text { 2. } 500 \mathrm{mg} \text { tablet twice daily of BPF Phytosome (*each table } \\
\text { equivalent to } 200 \mathrm{mg} \text { of BPF extract) } \\
\text { 3. Placebo tablets had no active ingredient } \\
\text { Study agents were taken } 30 \text { minutes before meals two times } \\
\text { daily }\end{array}$ & $\begin{array}{l}60(\mathrm{n}=20 \text { received } \mathrm{BPF}, \mathrm{n}=20 \text { received } \mathrm{BPF} \text { Phyto and } \mathrm{n}=20 \text { received } \\
\text { placebo }) \\
\text { Inclusion criteria: } \\
>120 \mathrm{mg} / \mathrm{dL} \text { LDL-C } \\
>175 \mathrm{mg} / \mathrm{dL} \text { Triglycerides } \\
>110 \mathrm{mg} / \mathrm{dL} \text { serum glucose }\end{array}$ & $\begin{array}{l}\text { Total Cholesterol } \\
\text { BPF } \\
\text { Day 0: } \quad 262 \pm 14 \\
\text { Day 30: } \quad 196 \pm 12 \\
\text { BPF Phyto } \\
\text { Day 0: } \quad 261 \pm 16 \\
\text { Day 30: } \quad 198 \pm 13 \\
\text { LDL-C } \\
\text { BPF } \\
\text { Day 0: } \quad 175.8 \pm 5.8 \\
\text { Day 30: } \quad 116 \pm 3.2 \\
\text { BPF Phyto } \\
\text { Day 0: } \quad 174 \pm 5.7 \\
\text { Day 30: } \quad 113 \pm 3.8 \\
\text { Triglycerides } \\
\text { BPF } \\
\text { Day 0: } \quad 252 \pm 9 \\
\text { Day 30: } 170 \pm 7 \\
\text { BPF Phyto } \\
\text { Day 0: } \quad 252 \pm 8 \\
\text { Day 30: } 173 \pm 6 \\
\text { HDL-C } \\
\text { BPF } \\
\text { Day 0: } \quad 44 \pm 4.1 \\
\text { Day 30: } 48 \pm 3.8 \\
\text { BPF Phyto } \\
\text { Day 0: } 44 \pm 4.4 \\
\text { Day 30: } 50 \pm 4.2 \\
\text { Glucose } \\
\text { BPF } \\
\text { Day 0: } \quad 120 \pm 1.6 \\
\text { Day 30: } 98 \pm 1.3 \\
\text { BPF Phyto } \\
\text { Day 0: } \quad 124 \pm 1.5 \\
\text { Day 30: } 96 \pm 1.4\end{array}$ \\
\hline Toth (2016) & $\begin{array}{l}\text { Open-label, } \\
\text { one-arm } \\
\text { Site: Palermo, } \\
\text { Italy }\end{array}$ & $\begin{array}{l}\text { Bergavit } R \circledast \text { (a Bergamot juice derived extract containing } 150 \\
\text { mg flavonoids) was given daily at a fixed dose for } 6 \text { months }\end{array}$ & $\begin{array}{l}80 \text { ( } 42 \text { men, } 38 \text { women }) \\
\text { Inclusion criteria: } \\
160-190 \mathrm{mg} / \mathrm{dL} \text { LDL-C } \\
\text { Must not have severe renal or hepatic diseases }\end{array}$ & $\begin{array}{l}\text { Total Cholesterol } \\
\text { Day 0: } 257 \pm 15 \\
6 \text { months: } 223 \pm 41 \\
\text { HDL-C } \\
\text { Day 0: } 48 \pm 10 \\
6 \text { months: } 52 \pm 14 \\
\\
\text { Triglycerides } \\
\text { Day 0: } 162 \pm 54 \\
6 \text { months: } 136 \pm 79 \\
\\
\text { LDL-C } \\
\text { Day 0: } 176 \pm 8 \\
6 \text { months: } 144 \pm 37\end{array}$ \\
\hline
\end{tabular}


Nauman MC (2019) Clinical application of bergamot (Citrus bergamia) for reducing high cholesterol and cardiovascular disease markers

\begin{tabular}{|c|c|c|c|c|}
\hline $\begin{array}{l}\text { Babish } \\
\text { (2016) }\end{array}$ & $\begin{array}{l}\text { Open-label, } \\
\text { one-arm } \\
\text { Site: California, } \\
\text { USA }\end{array}$ & $\begin{array}{l}2 \text { capsules of F } 105 \text { (total } 500 \mathrm{mg} \text { bergamot fruit extract and } \\
220 \mathrm{mg} \text { phytocomplex blend) were taken daily at dinnertime } \\
\text { for } 12 \text { weeks }\end{array}$ & $\begin{array}{l}11 \text { ( } 3 \mathrm{men}, 8 \text { women }) \\
\text { Inclusion criteria: } \\
18-40 \mathrm{~kg} / \mathrm{m}^{2} \mathrm{BMI} \\
150-30 \mathrm{mg} / \mathrm{ML} \text { LDL-C } \\
150-400 \mathrm{mg} / \mathrm{dL} \text { Triglycerides }\end{array}$ & $\begin{array}{l}\text { Cholesterol } \\
\text { Day 0: } 248 \text { (191-286) } \\
12 \text { weeks: } 228(197-266) \\
\text { LDL-C } \\
\text { Day 0: } 162(123-220) \\
12 \text { weeks: } 143 \text { (112-199) } \\
\text { Triglycerides } \\
\text { Day 0: } 186 \text { (118-473) } \\
12 \text { weeks: } 207 \text { (86-260) } \\
\text { HDL-C } \\
\text { Day 0: } 42 \text { (22-76) } \\
12 \text { weeks: } 42 \text { (26-68) } \\
\text { Non-HDL-C } \\
\text { Day 0: 214 (173-250) } \\
12 \text { weeks: } 222 \text { (152-242) } \\
\\
\text { Glucose } \\
\text { Day 0: } 94 \text { (82-228) } \\
12 \text { weeks: } 93 \text { (78-206) }\end{array}$ \\
\hline $\begin{array}{l}\text { Gliozzi } \\
\text { (2013) }\end{array}$ & $\begin{array}{l}\begin{array}{l}\text { Open-label, } \\
\text { parallel group, } \\
\text { placebo- } \\
\text { controlled }\end{array} \\
\text { Site: Rome, Italy }\end{array}$ & $\begin{array}{l}\text { 1. Placebo tablet had no active ingredient } \\
\text { 2. } 10 \mathrm{mg} \text { Rosuvastatin } \\
\text { 3. } 20 \mathrm{mg} \text { Rosuvastatin } \\
\text { 4. } 1000 \mathrm{mg} \mathrm{BPF}(+50 \mathrm{mg} \text { ascorbic acid) } \\
\text { 5. } 1000 \mathrm{mg} \mathrm{BPF} \mathrm{(}+50 \mathrm{mg} \text { ascorbic acid) }+10 \mathrm{mg} \text { Rosuvastatin } \\
\text { Study agents were taken before meals, once daily for } 30 \text { days }\end{array}$ & $\begin{array}{l}77(\mathrm{n}=15 \text { received placebo, } \mathrm{n}=16 \text { received low Rosuvastatin, } \mathrm{n}=16 \text { received } \\
\text { high Rosuvastatin, } \mathrm{n}=15 \text { received BPF, } \mathrm{n}=15 \text { received BPF+Rosuvastatin) } \\
\text { Inclusion criteria: } \\
>160 \mathrm{mg} / \mathrm{dL} \text { LDL-C } \\
>225 \mathrm{mg} / \mathrm{dL} \text { Triglycerides }\end{array}$ & 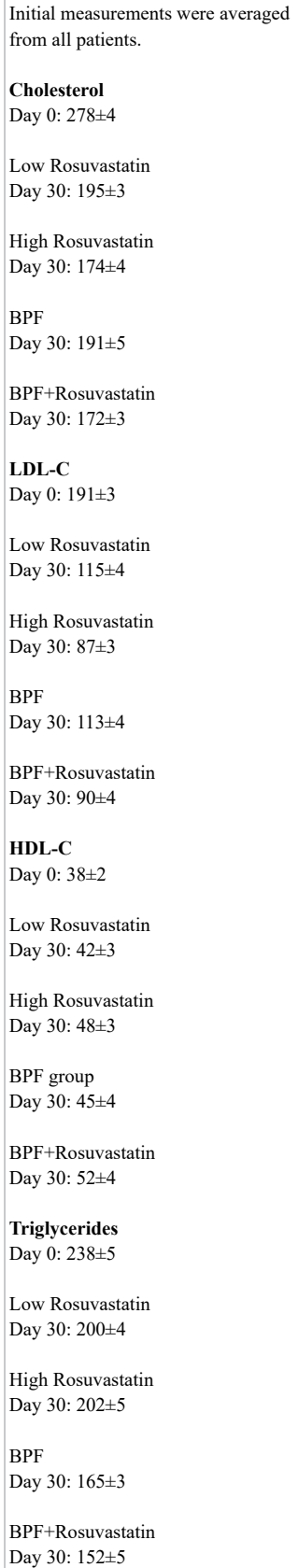 \\
\hline
\end{tabular}




\begin{tabular}{|c|c|c|c|c|}
\hline $\begin{array}{l}\text { Mollace } \\
\text { (2011) }\end{array}$ & $\begin{array}{l}\begin{array}{l}\text { Randomized, } \\
\text { double blind, } \\
\text { placebo- } \\
\text { controlled }\end{array} \\
\text { Site: Rome and } \\
\text { Marinella di } \\
\text { Bruzzano, Italy }\end{array}$ & $\begin{array}{l}\text { 1. } 500 \mathrm{mg} \mathrm{BPF} \mathrm{(}+50 \mathrm{mg} \text { ascorbic acid) } \\
\text { 2. } 1000 \mathrm{mg} \text { BPF ( }+50 \mathrm{mg} \text { ascorbic acid) } \\
\text { 3. Placebo tablet had no active ingredients } \\
\text { 4.For Group D only***-1500 mg BPF } \\
\text { Study agents were taken before meals, once daily, for } 30 \text { days }\end{array}$ & $\begin{array}{l}237 \\
\text { Group A - Hypercholesterolemia, } \mathrm{n}=104 \\
>130 \mathrm{mg} / \mathrm{dL} \text { LDL-C } \\
\text { Group B }- \text { Hypercholesterolemia+hypertriglyceridemia, } \mathrm{n}=42 \\
\text { Group C - Hypercholesterolemia+hypertriglyceridemia+hyperglycemia, } \\
\mathrm{n}=59 \\
>110 \mathrm{mg} / \mathrm{dL} \text { Glucose } \\
\text { Group D - patients who stopped simvastatin treatment due to muscular pain } \\
\text { or significant elevation of creatine-phospho-kinase, } \mathrm{n}=32 \\
\text { Each group (excluding Group D) was split into three smaller groups which } \\
\text { each received one of the study agents }\end{array}$ & 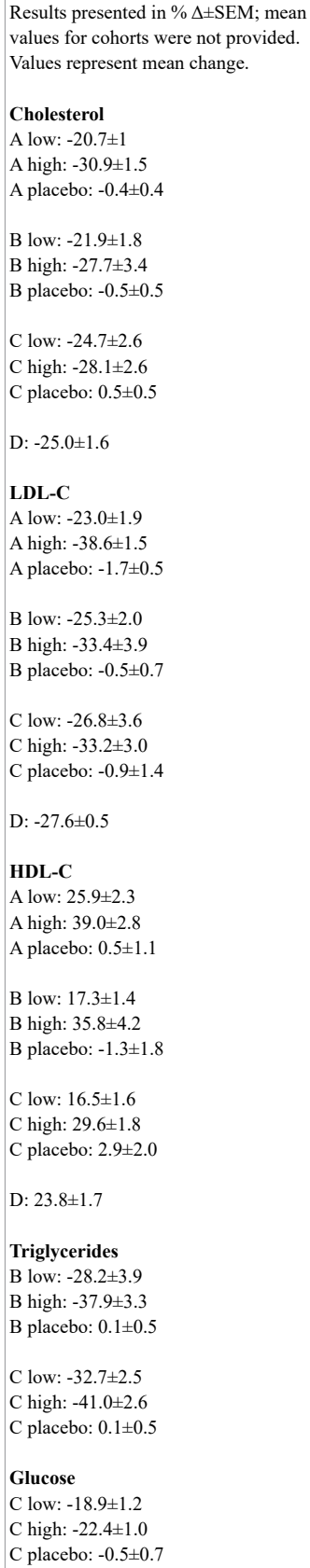 \\
\hline
\end{tabular}

to be largely based on molecular modeling and will require further studies to confirm this proposed mechanism of action. Taken together, these early clinical trials along with the mechanistic studies that have been performed suggest that bergamot can reduce total cholesterol and LDL-C through mechanisms that are distinct from current pharmaceutical approaches.

\section{Acknowledgements}

Johnson is supported by an NIH MERIT award (R37CA227101).

\section{Conflicts of interest}

The authors do not declare any conflicts of interest.

\section{References}

1. Mannucci C, Navarra M, Calapai F, Squeri R, Gangemi S, et al. (2017) Clinical pharmacology of Citrus bergamia: A systematic review. Phytother Res 31: 27-39. [Crossref]

2. Risitano R, Curro M, Cirmi S, Ferlazzo N, Campiglia P, et al. (2014) Flavonoid fraction of Bergamot juice reduces LPS-induced inflammatory response through SIRT1mediated NF-kappaB inhibition in THP-1 monocytes. PloS One 9: e107431. [Crossref]

3. Ferlazzo N, Visalli G, Smeriglio A, Cirmi S, Lombardo GE, et al. (2015) Flavonoid fraction of orange and bergamot juices protect human lung epithelial cells from hydrogen peroxide-induced oxidative stress. Evid Based Complement Alternat Med 2015: 957031.

4. Cirmi S, Bisignano C, Mandalari G, Navarra M (2016) Anti-infective potential of Citrus bergamia Risso et Poiteau (bergamot) derivatives: A systematic review. Phytother Res 30: 1404-1411. [Crossref] 
5. Marotta SM, Giarratana F, Parco A, Neri D, Ziino G, et al. (2016) Evaluation of the antibacterial activity of bergamot essential oils on different listeria monocytogenes strains. Ital J Food Saf 5: 6176. [Crossref]

6. Filocamo A, Bisignano C, Ferlazzo N, Cirmi S, Mandalari G, et al. (2015) In vitro effect of bergamot (Citrus bergamia) juice against cagA-positive and-negative clinical isolates of Helicobacter pylori. BMC Complement Altern Med 15: 256. [Crossref]

7. Abbasi J (2019) New cholesterol guidelines personalize risk and add treatments. JAMA. [Crossref]

8. Nunes JP (2017) Statins and the cholesterol mortality paradox. Scott Med J 62: 19-23. [Crossref]

9. Alsheikh-Ali AA, Karas RH (2009) The relationship of statins to rhabdomyolysis, malignancy, and hepatic toxicity: Evidence from clinical trials. Curr Atheroscler Rep 11: 100-104. [Crossref]

10. Joy TR, Hegele RA (2009) Narrative review: Statin-related myopathy. Ann Intern Med 150: 858-868. [Crossref]

11. Navarra M, Ferlazzo N, Cirmi S, Trapasso E, Bramanti P, et al. (2015) Effects of bergamot essential oil and its extractive fractions on SH-SY5Y human neuroblastoma cell growth. J Pharm Pharmacol 67: 1042-1053. [Crossref]

12. Dugo P, Presti ML, Ohman M, Fazio A, Dugo G, et al. (2005) Determination of flavonoids in citrus juices by micro-HPLC-ESI/MS. J Sep Sci 28: 1149-1156. [Crossref]

13. Caristi C, Bellocco E, Panzera V, Toscano G, Vadalà R, et al. (2003) Flavonoids detection by HPLC-DAD-MS-MS in lemon juices from Sicilian cultivars. $J$ Agric Food Chem 51: 3528-3534. [Crossref]

14. Gattuso G, Barreca D, Gargiulli C, Leuzzi U, Caristi C (2007) Flavonoid composition of citrus juices. Molecules 12: 1641-1673. [Crossref]

15. Nogata Y, Sakamoto K, Shiratsuchi H, Ishii T, Yano M, et al. (2006) Flavonoid composition of fruit tissues of citrus species. Biosci Biotechnol Biochem 70: 178-192. [Crossref]

16. Tranchida PQ, Presti ML, Costa R, Dugo P, Dugo G, et al. (2006) High-throughput analysis of bergamot essential oil by fast solid-phase microextraction-capillary gas chromatography-flame ionization detection. J Chromatogr A 1103: 162-165. [Crossref]

17. Yu J, Wang L, Walzem RL, Miller EG, Pike LM, et al. (2005) Antioxidant activity of citrus limonoids, flavonoids, and coumarins. J Agric Food Chem 53: 2009-2014. [Crossref]

18. Choe SC, Kim HS, Jeong TS, Bok SH, Park YB (2001) Naringin has an antiatherogenic effect with the inhibition of intercellular adhesion molecule-1 in hypercholesterolemic rabbits. J Cardiovasc Pharmacol 38: 947-955. [Crossref]

19. van de Stolpe A, van der Saag PT (1996) Intercellular adhesion molecule-1. J Mol Med (Berl) 74: 13-33. [Crossref]

20. Mollace V, Ragusa S, Sacco I, Muscoli C, Sculco F, et al. (2008) The protective effect of bergamot oil extract on lecitine-like oxyLDL receptor-1 expression in balloon injuryrelated neointima formation. J Cardiovasc Pharmacol Ther 13: 120-129. [Crossref]
21. Kaplan R, Aynedjian HS, Schlondorff D, Bank N (1990) Renal vasoconstriction caused by short-term cholesterol feeding is corrected by thromboxane antagonist or probucol. $J$ Clin Invest 86: 1707-1714. [Crossref]

22. Trovato A, Taviano MF, Pergolizzi S, Campolo L, De Pasquale R, et al. (2010) Citrus bergamia Risso \& Poiteau juice protects against renal injury of diet-induced hypercholesterolemia in rats. Phytother Res 24: 514-519. [Crossref]

23. Di Donna L, De Luca G, Mazzotti F, Napoli A, Salerno R, et al. (2009) Statin-like principles of bergamot fruit (Citrus bergamia): Isolation of 3-hydroxymethylglutaryl flavonoid glycosides. $J$ Nat Prod 72: 1352-1354. [Crossref]

24. Leopoldini M, Malaj N, Toscano M, Sindona G, Russo N (2010) On the inhibitor effects of bergamot juice flavonoids binding to the 3-hydroxy-3-methylglutaryl-CoA reductase (HMGR) enzyme. J Agric Food Chem 58: 10768-10773. [Crossref]

25. Qu H, Meng YY, Chai H, Liang F, Zhang JY, et al. (2018) The effect of statin treatment on circulating coenzyme Q10 concentrations: An updated meta-analysis of randomized controlled trials. Eur J Med Res 23: 57. [Crossref]

26. Pu P, Gao DM, Mohamed S, Chen J, Zhang J, et al. (2012) Naringin ameliorates metabolic syndrome by activating AMP-activated protein kinase in mice fed a high-fat diet. Arch Biochem Biophys 518: 61-70. [Crossref]

27. Sui GG, Xiao HB, Lu XY, Sun ZL (2018) Naringin activates AMPK resulting in altered expression of SREBPs, PCSK9, and LDLR to reduce body weight in obese C57BL/6J mice. J Agric Food Chem 66: 8983-8990. [Crossref]

28. Miceli N, Mondello MR, Monforte MT, Sdrafkakis V, Dugo P, et al. (2007) Hypolipidemic effects of Citrus bergamia Risso et Poiteau juice in rats fed a hypercholesterolemic diet. J Agric Food Chem 55: 10671-10677. [Crossref]

29. Musolino V, Gliozzi M, Carresi C, Maiuolo J, Mollace R, et al. (2017) Lipid-lowering effect of bergamot polyphenolic fraction: Role of pancreatic cholesterol ester hydrolase. J Biol Regul Homeost Agents 31: 1087-1093. [Crossref]

30. Mollace V, Scicchitano M, Paone S, Casale F, Calandruccio C, et al. (2018) Hypoglycemic and Hypolipemic effects of a new lecithin formulation of Bergamot polyphenolic fraction: A double blind, randomized, placebo-controlled study. Endocr Metab Immune Disord Drug Targets. [Crossref]

31. Toth PP, Patti AM, Nikolic D, Giglio RV, Castellino G, et al. (2015) Bergamot reduce plasma lipids, atherogenic small dense LDL, and subclinical atherosclerosis in subjects with moderate hypercholesterolemia: A 6 months prospective study. Front Pharmacol 6: 299. [Crossref]

32. Babish JG, Dahlberg CJ, Ou JJ, Keller WJ, Gao W, et al. (2016) Synergistic in vitro antioxidant activity and observational clinical trial of F105, a phytochemical formulation including Citrus bergamia, in subjects with moderate cardiometabolic risk factors. Can J Physiol Pharmacol 94: 1257-1266. [Crossref]

33. Gliozzi M, Walker R, Muscoli S, Vitale C, Gratteri S, et al. (2013) Bergamot polyphenolic fraction enhances rosuvastatin-induced effect on LDL-cholesterol, LOX1 expression and protein kinase B phosphorylation in patients with hyperlipidemia. Int J Cardiol 170: 140-145. [Crossref]

34. Mollace V, Sacco I, Janda E, Malara C, Ventrice D, et al. (2011) Hypolipemic and hypoglycaemic activity of bergamot polyphenols: From animal models to human studies. Fitoterapia 82: 309-316. [Crossref]

Copyright: C2019 Nauman MC. This is an open-access article distributed under the terms of the Creative Commons Attribution License, which permits unrestricted use, distribution, and reproduction in any medium, provided the original author and source are credited. 